\title{
Intracellular antagonistic interaction between GnRH and gonadotrophin surge-inhibiting/attenuating factor bioactivity downstream of second messengers involved in the self-priming process
}

\author{
A. M. I. Tijssen, M. N. Helder, Z-W. Chu and J. de Koning* \\ Division of Medical Pharmacology of the Leiden/Amsterdam Center for Drug Research, \\ Sylvius Laboratories, University of Leiden, PO Box 9503, 2300 RA Leiden. The Netherlands
}

\begin{abstract}
The antagonistic control of LH concentrations by $\mathrm{GnRH}$ and the putative ovarian factor gonadotrophin surge-inhibiting or -attenuating factor (GnSIF/AF) was studied by perifusion of female rat pituitary glands in vitro. $\mathrm{LH}$ release and GnRH self-priming were measured in response to five $\left(0.32-10 \mathrm{nmol} \mathrm{l}^{-1}\right)$ or three $\left(10 \mathrm{nmol} \mathrm{l}^{-1}\right) 10$ min pulses of $\mathrm{GnRH}$. In the latter case, pulses were preceded by five $10 \mathrm{~min}$ pulses of either $1 \mathrm{mmol} 8$-bromo-cAMP $1^{-1}$ plus $10 \mathrm{mmol}$ theophylline $1^{-1}$ or $1 \mu \mathrm{mol}$ phorbol 12 -myristate 13 -acetate $l^{-1}$. The stimulations were carried out in the presence or absence of steroid-free bovine follicular fluid, which possesses GnSIF/AF bioactivity, to study the effect of GnSIF/AF on the self-priming process during successive stimulations by $\mathrm{GnRH}$. First, the effect of follicular fluid was studied on GnRH-induced LH release from pituitary glands collected during the ovarian cycle. Only when a clear self-priming effect was evident, as on day 2 of dioestrus and the day of pro-oestrus, follicular fluid antagonized the self-priming effect of GnRH. Second, when glands on day 2 of dioestrus were used, self-priming was displayed by various combinations of GnRH and follicular fluid. The pulses with the lowest concentrations of GnRH together with a high concentration of follicular fluid, however, led to stable low amplitude LH pulses. Finally, priming of the pituitary LH response to GnRH with 8-bromo-cAMP plus theophylline or phorbol 12-myristate 13-acetate was inhibited by follicular fluid. These results confirm the control of LH release by GnRH and GnSIF/AF bioactivity. The effect of GnSIF/AF in follicular fluid is most pronounced on the days before the $\mathrm{LH}$ surge, showing evidence of its important role in maintaining low $\mathrm{LH}$ concentrations during this period. GnSIF/AF neutralizes downstream actions of second messengers involved in GnRH self-priming.
\end{abstract}

\section{Introduction}

Exposure of pituitary glands of female rats to GnRH during the 2 days preceding ovulation induces a very characteristic biphasic LH secretion pattern in vivo and in vitro (Aiyer et al., 1974; De Koning et al., 1976; Pickering and Fink, 1976; Schuiling et al., 1976). The initial response to GnRH remains low for about $0.5-1.0 \mathrm{~h}$, the time necessary for the synthesis and biological processing of proteins that constitute the rate-limiting step in LH release (De Koning et al., 1976; Pickering and Fink, 1976; Waring and Turgeon, 1980; Evans et al., 1984; Busbridge et al., 1990). After this lag-phase, a $\mathrm{GnRH}$-induced increased secretion of $\mathrm{LH}$ is allowed by these newly synthesized pituitary proteins: the GnRH-self-priming effect. It has been hypothesized that during the ovarian cycle

${ }^{*}$ Correspondence.

Received 13 March 1997. the synthesis of these so-called self-priming-associated proteins (SPAP), or their biological effects, are neutralized by a putative ovarian protein factor. This protein, also named gonadotrophin surge-inhibiting or -attenuating factor (GnSIF/AF) prevents and eliminates endogenous self-priming (De Koning et al., 1979, 1980; Busbridge et al., 1990; Knight et al., 1990; Koppenaal et al., 1991, 1993; De Koning, 1995; Van Dieten and De Koning, 1995; Fowler and Templeton, 1996). In this way, GnSiF/AF and GnRH constitute a functional antagonistic system to stabilize low $\mathrm{LH}$ concentrations during the major part of the ovarian cycle (here the effect of GnSIF/AF is reiatively stronger), but also to allow the preovulatory $\mathrm{LH}$ surge (here the effect of GnRH is relatively stronger; for more details see De Koning, 1995).

Normally, pulsatile administration of GnRH leads to the self-priming effect in phenobarbital-blocked rats. Low physiological concentrations of LH were maintained in such rats by the administration of a low concentration, pulsatile $\mathrm{GnRH}$ 
regimen, which demonstrated the effectiveness of endogenous GnSIF/AF for neutralizing the self-priming action of GnRH between these pulses (Van Dieten and De Koning, 1995). In the present study, the antagonistic interaction between $\mathrm{GnRH}$ and GnSIF/AF bioactivity (as present in bovine follicular fluid (bFF)) was tested directly at the pituitary by a dynamic in vitro design consisting of a perifusion system with hemi-pituitaries. Besides $\mathrm{GnRH}$, agents that mimic the action of the second messengers, cAMP and diacylglycerol (DAG), were also used to induce $\mathrm{LH}$ release and the priming effect (De Koning et al., 1981; Turgeon and Waring, 1986; Bourne et al., 1989; Mitchell et al., 1994; Abdilnour and Bourne, 1995).

\section{Materials and Methods}

\section{Animals}

Adult female rats $(200-240 \mathrm{~g})$ from the Wistar-derived colony kept in this laboratory were allowed free access to food and water. The animal room was illuminated from 07.00 to $19.00 \mathrm{~h}$ and was kept at a constant temperature of $22^{\circ} \mathrm{C}$. Vaginal smears were taken once per day. Only those rats that had at least two regular consecutive 4 day cycles were selected.

\section{Perifusions}

Female rats were decapitated between 08.00 and $08.30 \mathrm{~h}$, the pituitary glands were halved and each half was placed in a perifusion chamber. The halves of the same pituitary gland were always divided among different experimental groups. A maximum of eight columns was run at the same time. All perifusion media were supplemented with $0.3 \%(\mathrm{w} / \mathrm{v})$ bovine serum albumin (FLUKA, Buchs; this prevents adhesions of the reagents and hormones to the inner walls of the perifusion system), $35 \mathrm{mg}$ penicillin $\mathrm{ml}^{-1}$ (Gist-Brocades NV, Delft) and $50 \mathrm{mg}$ gentamicin $1^{-1}$ (Sigma Chemical Company, St Louis, $\mathrm{MO}$ ). The pituitary tissues were perifused for $2 \mathrm{~h}$ at $37^{\circ} \mathrm{C}$ with $95 \% \mathrm{O}_{2}: 5 \% \mathrm{CO}_{2}$ saturated TCM 199 (Boehringer, Mannheim). During this time, $\mathrm{LH}$ concentrations in the media fell gradually and stabilized at a low baseline concentration (data not shown). The perifusion was then continued with medium to which either bFF (aspirated from follicles of ovaries obtained from the local abattoir and made steroid-free by charcoal treatment; De Koning et al., 1989) or an equivalent amount of charcoaltreated serum from ovariectomized rats was added. If used, bFF and the control serum were present throughout the experiment. If cycloheximide $\left(90 \mu \mathrm{mol} \mathrm{l}{ }^{-1}\right.$; Boehringer $)$ was used, it was present during and after the GnRH stimulations. Ten minute pulses of GnRH (10 nmol l-1; Boehringer) or of 8-bromo-cAMP (Boehringer) plus theophylline (BrcAMP/theo, 1 mmol $1^{-1}$ plus $10 \mathrm{mmol} \mathrm{l}^{-1}$; Sigma-Aldrich, Deisenhofen) or phorbol 12-myristate 13-acetate (PMA; $1 \mu \mathrm{mol} 1^{-1}$; SigmaAldrich) were led through the columns. The perifusion chambers were made from $1 \mathrm{ml}$ Primo plastic syringes (ASIK, Rødby) and had a volume of $100 \mu \mathrm{l}$. The perifusion velocity was $7.8 \mathrm{mi} \mathrm{h}^{-1}$. Ten minute fractions of media were collected and samples were taken and assayed for LH. Each treatment group consisted of pituitary tissues from at least five rats.

\section{Experimental design}

Experiment 1. The effects on LH release from pituitary halves were studied during five successive $10 \mathrm{~min}$ pulses of GnRH $\left(0.32,1.0,3.2\right.$ or $\left.10 \mathrm{nmol} 1^{-1}\right)$ in the absence or

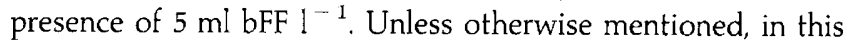
and the following experiments, pituitary glands were collected on the morning of day 2 of dioestrus. All pulses were separated by $50 \mathrm{~min}$ of perifusion with the same medium but without the secretagogue.

Experiment 2. The effects on $\mathrm{LH}$ release from pituitary halves were studied during five successive $10 \mathrm{~min}$ pulses of $1 \mathrm{nmol} \mathrm{GnRH} \mathrm{I}{ }^{-1}$ in the absence or presence of various doses of bFF (1.25, 2.5 and $\left.5.0 \mathrm{ml} \mathrm{l}^{-1}\right)$. In a separate experiment, concentrations of 0.32 and $1.0 \mathrm{nmol} 1^{-1} \mathrm{GnRH}$ were used, and the dose of bFF was increased to $10 \mathrm{ml} \mathrm{l}^{-1}$.

Experiment 3. The effects on LH release from pituitary halves were studied during five successive $10 \mathrm{~min}$ pulses of $10 \mathrm{nmol} \mathrm{GnRH} 1^{-1}$ in the absence or presence of $10 \mathrm{ml} b F F$ $1^{-1}$. Pituitary glands were collected on the morning of each day of the ovarian cycle.

Experiment 4. The purpose of this experiment was to determine whether the GnSIF/AF bioactivity in bFF could neutralize the effect of second messengers involved in the self-priming action of GnRH. Therefore, pituitary halves were exposed to five successive $10 \mathrm{~min}$ pulses of medium only or medium containing BrcAMP/theo $\left(1 / 10 \mathrm{mmol} \mathrm{l^{-1 }}\right)$ or PMA ( $1 \mu \mathrm{mol} \mathrm{l^{-1 }}$ ), all in the presence or absence of $10 \mathrm{ml} \mathrm{bFF} \mathrm{l}^{-1}$. Their respective effects on priming of the pituitary gland were tested during three successive $10 \mathrm{~min}$ pulses of $10 \mathrm{nmol} \mathrm{GnRH}$ $1^{-1}$ with or without the protein synthesis inhibitor cycloheximide. GnRH self-priming is dependent on de novo synthesis of proteins which allows the increased rate of $\mathrm{LH}$ release. During inhibition of protein synthesis, the initial height of the rate of GnRH-induced LH release should reflect whether or not synthesis of these proteins has already taken place during the $5 \mathrm{~h}$ treatment with the various secretagogues. If added, bFF was present throughout the $8 \mathrm{~h}$ of perifusion.

\section{Radioimmunoassay of $L H$}

The assay was carried out as described by De Koning et al. (1987). The intra- and interassay coefficients of variation were $8.1 \%$ and $11.4 \%$, respectively. Specific anti-ovine $\mathrm{LH}$ was a generous gift from J. Th. J. Uilenbroek (Erasmus University, Rotterdam). Rat LH-I-6 and LH-RP-3 (both kindly provided by the NHPP, NIDDK, NICHHD) were used for iodination and as standard preparation, respectively. The sensitivity of the assays, defined as the amount of the standard required to suppress binding of iodinated LH to $90 \%$ of that occurring without unlabelled LH was $72 \pm 18$ (mean \pm s.D.) pg per tube $(n=20)$.

The results are expressed as the total amount of LH-RP3 released $\mathrm{h}^{-1} \mathrm{I}^{-1}$ (area under the curve) in response to each GnRH stimulus, corrected for basal LH release (the area under the curve was calculated from the absolute LH concentration 


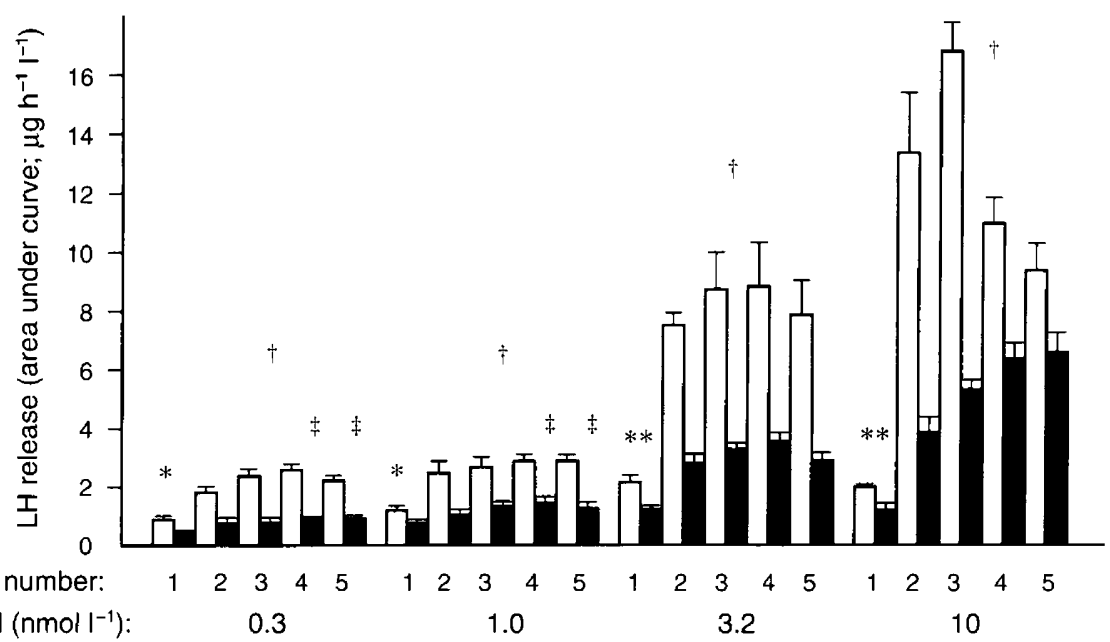

Fig. 1. The effects on the LH response (mean area under curves; amount of LH-RP3 released $\mathrm{h}^{-1}$ $1^{-1} \pm$ SEM; $n=5$ ) of hemi-pituitaries during five successive $10 \mathrm{~min}$ pulses with $0.32,1.0,3.2$ or $10 \mathrm{nmol} \mathrm{GnRH} \mathrm{^{-1 }}$ in the absence ( $\square$ ) or presence ( $\square$ ) of $5 \mathrm{ml}$ bovine follicular fluid (bFF) $\mathrm{l}^{-1}$. The pituitary glands were collected on the morning of day 2 of dioestrus. The pulses were separated by $50 \mathrm{~min}$ of perifusion with the same medium but without $\mathrm{GnRH}$. ${ }^{\dagger} \mathrm{LH}$ response (all pulse numbers) was decreased significantly by bFF; *first LH pulse was significantly lower than all subsequent pulses of the same treatment; ${ }^{\ddagger}$ pulses were significantly increased compared with the response during the first pulse of the same treatment. In all cases $P<0.05$ (Duncan's multiple comparison test).

measured during the $10 \mathrm{~min}$ before the stimulus and $1 \mathrm{~h}$ later). In most cases after $\mathrm{GnRH}$ stimulation, $\mathrm{LH}$ concentrations returned to basal values within $I \mathrm{~h}$. However, in response to the two highest concentrations of $\mathrm{GnRH}$, these baseline concentrations remained moderately high.

\section{Statistical analysis}

Statistical comparisons were made by analysis of variance and then by Duncan's multiple comparison test (Steel and Torrie, 1960). If the data showed heterogeneity of variance, logarithmic transformation was carried out before statistical analysis. A difference was considered significant when analysis of variance showed heterogeneity for the whole group and the muitiple comparison test gave a value of $P<0.05$ for the two groups concerned.

\section{Results}

\section{Experiment 1}

The time course effects of five successive $10 \mathrm{~min}$ pulses of GnRH $\left(0.32,1.0,3.2\right.$ or $\left.10 \mathrm{nmol} \mathrm{I}^{-1}\right)$ on LH release from the pituitary gland and the effect of $5 \mathrm{ml} \mathrm{bFF} \mathrm{l}^{-1}$ are shown (Fig. 1). Each dose regimen of $\mathrm{GnRH}$ displayed the self-priming phenomenon. The magnitude of the response was most pronounced with the highest pulse dosages of $\mathrm{GnRH}$. The inclusion of bFF significantly attenuated the first response to $\mathrm{GnRH}$ and the self-priming process. Furthermore, it significantly delayed the development of self-priming in response to the two lowest concentrations of GnRH. At the highest dosages, and only in the absence of bFF, the LH response to GnRH desensitized.

Addition of bFF into the medium did not affect absolute basal concentrations of $\mathrm{LH}$. In both cases these concentrations were $3.5 \pm 0.5 \mu \mathrm{g} \mathrm{LH}-\mathrm{RP} 3 \mathrm{l}^{-1}$ (mean $\pm \mathrm{SEM} ; n=15$ ).

\section{Experiment 2}

It was investigated whether a concentration of bFF could antagonize completely the self-priming action of a submaximally active concentration of $\mathrm{GnRH}$. First, the effect was studied of various amounts of bFF $\left(1.25-10.0 \mathrm{ml} \mathrm{l}^{-1}\right)$ on LH release stimulated by five successive pulses of $1 \mathrm{nmol}$ $\mathrm{GnRH}{ }^{-1}$. The self-priming efficiency of this dose of GnRH decreased when the highest concentrations of bFF were applied (Fig. 2a). GnRH self-priming consistently remained apparent;

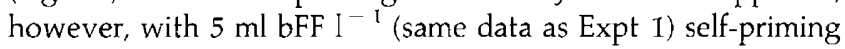
was delayed.

In a subsequent experiment, the pituitary glands were exposed to five successive $10 \mathrm{~min}$ pulses of $0.32 \mathrm{nmol} \mathrm{GnRH}$ $1^{-1}$ in the presence and absence of $10 \mathrm{ml} \mathrm{bFF} 1^{-1}$. In this case, GnRH self-priming was completely prevented by bFF and an almost steady low pulsatile release of LH occurred (Fig. 2b). In the control without bFF, GnRH self-priming was still evident.

\section{Experiment 3}

The results of the effects of $10 \mathrm{ml} \mathrm{bFF} 1^{-1}$ and five successive $10 \mathrm{~min}$ pulses of $10 \mathrm{nmol} \mathrm{GnRH} 1^{-1}$ on $\mathrm{LH}$ releasefrom pituitary glands collected throughout the ovarian cycle are shown (Fig. 3). They confirm that GnRH self-priming 


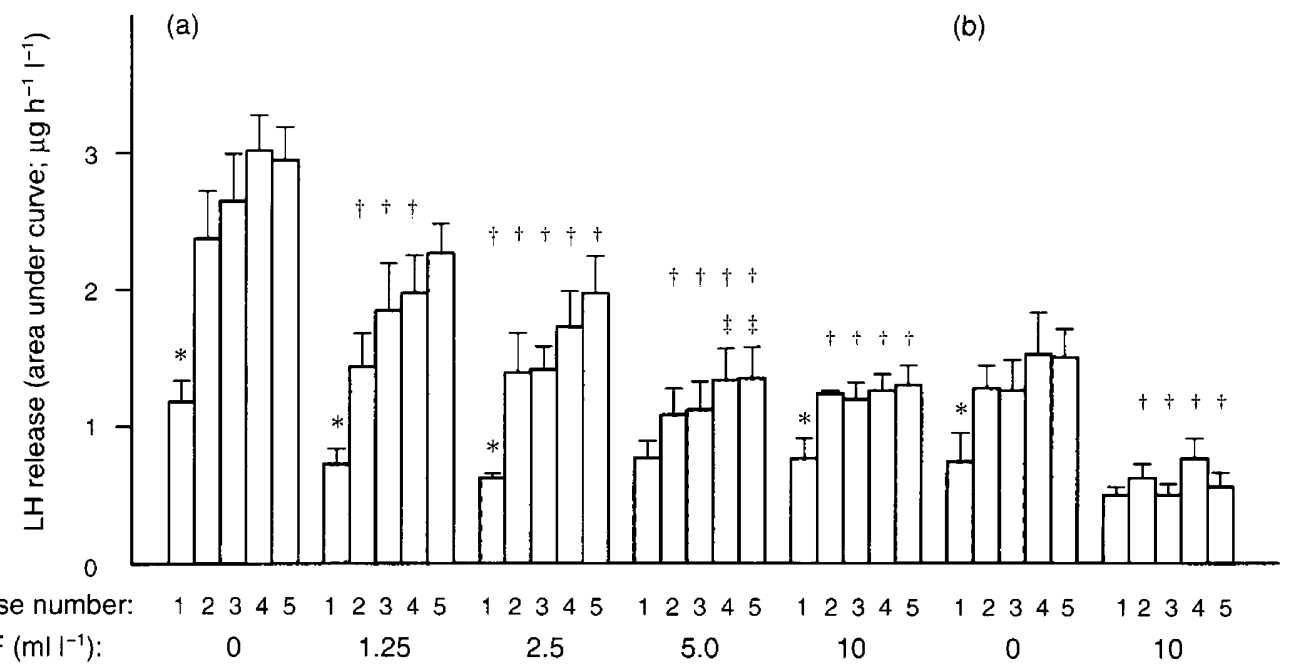

Fig. 2. The effects on the LH response (mean area under curves; amount of LH-RP3 released $h^{-1} l^{-1} \pm$ SEM) of hemi-pituitaries during five successive $10 \mathrm{~min}$ pulses with (a) $1 \mathrm{nmol} \mathrm{I}^{-1}(n=5)$ or (b) $0.32 \mathrm{ng} \mathrm{1^{-1 }}(n=7)$ $\mathrm{GnRH}$ and $0,1.25,2.5,5$ or $10 \mathrm{ml}$ bovine follicular fluid $\mathrm{l}^{-1}(\mathrm{bFF})$. The pituitary glands were collected on the morning of day 2 of dioestrus. The pulses were separated by $50 \mathrm{~min}$ of perifusion with the same medium but without GnRH. The experiments with the different concentrations of $\mathrm{GnRH}$ were carried out separately. ${ }^{\dagger} \mathrm{LH}$ responses are significantly decreased by bFF as compared with the time-matched controls; ${ }^{*}$ first LH pulse is significantly lower than all subsequent pulses of the same treatment; ${ }^{*}$ pulses are significantly increased compared with the response during the first pulse of the same treatment. In all cases $P<0.05$ (Duncan's multiple comparison test).

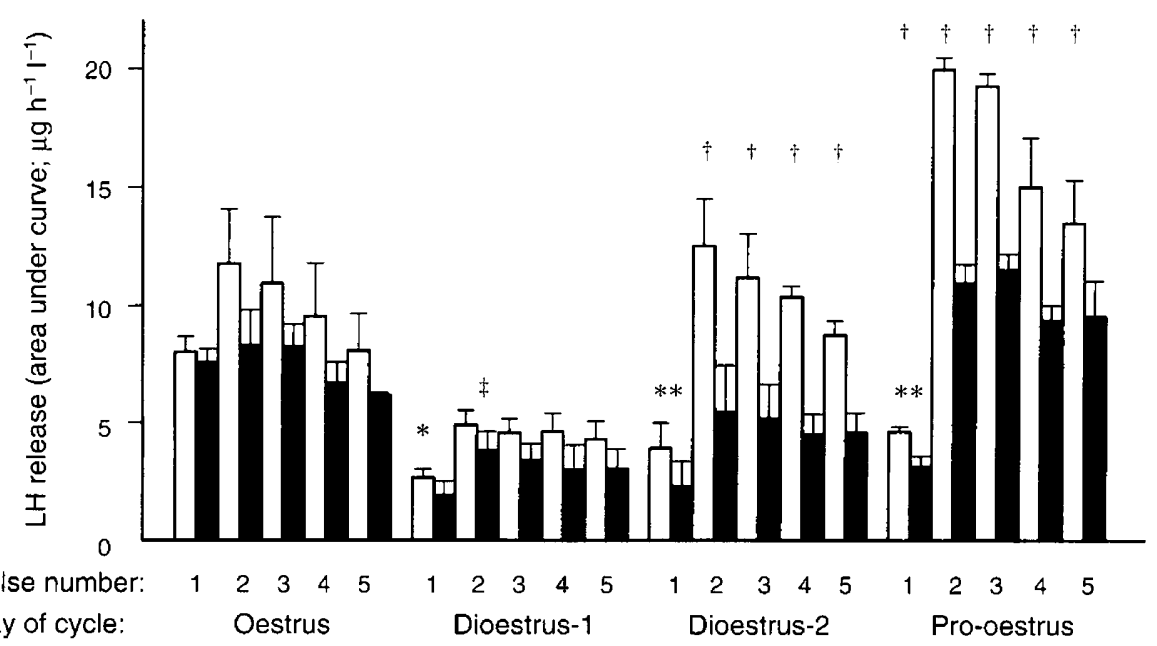

Fig. 3. The effects on the LH response imean area under curves; amount of LH-RP3 released $h^{-1}$ $1^{-1} \pm \mathrm{SEM}$ ) of hemi-pituitaries during five successive $10 \mathrm{~min}$ pulses with $10 \mathrm{nmol} \mathrm{GnRH} l^{-1}$ in the absence $(\square)$ or presence $(\boldsymbol{Q})$ of $10 \mathrm{ml}$ bovine follicular fluid (bFF) $\mathrm{l}^{-1}$. The pituitary glands were collected on the morning of each day of a 4 day ovarian cycle. The pulses were separated by $50 \mathrm{~min}$ of perifusion with the same medium but without GnRH. ${ }^{\dagger}$ On these days the LH responses are decreased significantly by bFF, except the first response on days 1 and 2 of dioestrus; *first LH pulse is significantly lower than all subsequent pulses of the same treatment; ${ }^{\ddagger}$ puise is significantly increased compared with the response during the first pulse of the same treatment. In all cases $P<0.05$ (Duncan's multiple comparison test).

was most pronounced on day 2 of dioestrus and the day of pro-oestrus. On day 1 of dioestrus in both groups, a small but significant self-priming was noticed, whereas at oestrus, no self-priming was displayed. Inclusion of bFF into the media showed significant effects on GnRH-induced LH release only when GnRH self-priming was most significant, that is on day 2 of dioestrus and the day of pro-oestrus.

The results again demonstrate that, in the absence of bFF, the $\mathrm{GnRH}$ pulses desensitize the pituitary to the action of GnRH. 


\section{Experiment 4}

The effects on the induction of the priming process were studied of five successive 10 min pulses of medium only, or medium with BrcAMP/theo or PMA, all in the presence or absence of bFF (Fig. 4). After the fifth pulse, the LH responses were measured during three additional $10 \mathrm{~min}$ exposures to $10 \mathrm{nmol} \mathrm{GnRH} \mathrm{l}^{-1}$ in the presence or absence of cycloheximide. During the GnRH challenge period, BrcAMP/theo and PMA were not included in the media.

The response to the fifth $10 \mathrm{~min}$ exposures of the above agents and the absolute LH concentrations of this response during the last $10 \mathrm{~min}$ (Fig. 4a,b) show that neither PMA nor $\mathrm{BrcAMP} /$ theo, in the presence or absence of $\mathrm{bFF}$, caused a significant LH pulse. PMA in the presence and absence of $b F F$ significantly increased the absolute LH concentrations, whereas BrcAMP/theo was without effect. This action of PMA was attenuated by the inclusion of bFF into the media.

After $5 \mathrm{~h}$ exposure to medium only (Fig. 4c), after the second and third GnRH pulse, a moderate but clear protein synthesis-dependent $\mathrm{GnRH}$ self-priming was observed. In agreement with previous experiments (De Koning et al., 1989), the inclusion of bFF into the media decreased the initial phase of low LH release stimulated by $\mathrm{GnRH}$, and thereafter a clear self-priming was displayed. The responses to the third $\mathrm{GnRH}$ pulses were no longer significantly different from the control values. In addition, this increase in the rate of L.H release was dependent on protein synthesis.

The priming capacity of PMA and of BrcAMP/theo, in the absence of bFF, to the subsequent exposures to $\mathrm{GnRH}$ are shown (Fig. 4d,e). PMA was the most effective inducer of priming of the pituitary responsiveness to the first pulse of $\mathrm{GnRH}$. However, the latter effect had disappeared already at the second GnRH pulse. The primed state after BrcAMP/theo treatment remained permanent, but decreased during the concomitant exposure to cycloheximide. This inhibitor of protein synthesis did not significantly affect the action of PMA. The inclusion of bFF into the media blocked the priming effect of BrcAMP/theo on the action of GnRH, but only partly blocked the effect of PMA. However, during the second and third pulse of the GnRH challenge, the self-priming phenomenon was restored. This was most clearly seen after the BrcAMP/theo treatment, when the maximal self-priming effect was reached and, as expected, could be prevented by inclusion of cycloheximide into the media. The GnRH-induced self-priming after the PMA plus bFF treatment was also prevented by inhibition of protein synthesis.

\section{Discussion}

Since GnSIF/AF is still not available in sufficient quantities, bFF was used as a substitute for GnSIF/AF bioactivity. Although the results were not always consistent, GnSIF/AF bioactivity may also be an intrinsic feature of two other hormones present in bFF: inhibin and follistatin (Farnworth et al., 1988; Jakubowiak et al., 1989, 1990; Weiss et al., 1993; Tio et al., 1994; see also De Koning, 1995 and Fowler and Templeton, 1996). Two purified preparations of GnSIF/AF were partly characterized, each consisting of a different single polypeptide chain (Tio et al., 1994; Danforth and Cheng, 1995). Apart from being unique proteins, differences between inhibin and GnSIF/AF bioactivity have been demonstrated. In FSH-treated women, Muttukrishna et al. (1994) showed a change in GnSIF/AF bioactivity before a significant change in blood concentrations of immunoreactive inhibin. Animal experiments in which FSH-stimulated GnSIF/AF bioactivity was immunoneutralized by inhibin antibodies exposed the intrinsic GnSIF/AF bioactivity of inhibin (Culler and Negro-Vilar, 1989; Culler, 1992). Studies in vitro using purified ovine (Campen and Vale, 1988), bovine (Farnworth et al., 1988), rat (Tio et al, 1994) and recombinant human (Woodruff et al., 1993) inhibin demonstrated that inhibin has some GnSIF/AF-like bioactivity. Thus, GnSIF/AF bioactivity in bFF may stem from different proteins. However, since these proteins are also present in the blood, they may be part of the total circulating GnSIF/AF bioactivity, and may, therefore, contribute to the effect of endogenous GnSIF/AF on the LH responsiveness of the pituitary gland to $\mathrm{GnRH}$.

The small but regular pulsatile LH blood patterns displayed during the major part of the rat ovarian cycle implicate an approximate $1 \mathrm{~h}$ frequency of GnRH release (Gallo, 1981a, b; Kalra, 1993). The absence of an endogenous self-priming process in response to the GnRH pulse-generator has been demonstrated (Padmanabhan et al., 1982; De Koning, 1995; Van Dieten and De Koning, 1995). By administration of only small amounts of GnRH once per hour in phenobarbital blocked rats, similar, physiological-like LH pulses were induced. Thus, the action of GnSIF/AF that neutralizes the self-priming effect after each pulse of endogenous $\mathrm{GnRH}$ was reproduced. This action of GnSIF/AF keeps the pituitary in an inhibited state to the next pulse of GnRH (Van Dieten and De Koning, 1995).

Use of the present dynamic in vitro design shows that GnRH-induced self-priming was antagonized by the inclusion of bFF. Moreover, bFF completely eliminated the self-priming effect of a low concentration pulsatile GnRH regimen, confirming the results in vivo. It may be assumed that a similar biological entity in bFF (that is, putative GnSIF/AF) is responsible for the neutralization of the increased LH responsiveness after GnRH exposure in vivo and in vitro (De Koning, 1995; Van Dieten and De Koning, 1995).

The results show that administration of this factor is effective only on those days when the GnRH self-priming is evident. Stabilization of LH concentrations during the 2 days preceding the $\mathrm{LH}$ surge is of the most importance. The inability of bFF to affect GnRH-induced LH release by the pituitary gland early in the cycle may be a consequence of the preceding stimulation by the preovulatory GnRH surge. Similarly, FSH, which may increase the release of GnSIF/AF, is not effective early in the cycle of the rat. A similar insensitivity to the action of GnSIF/AF is found in sheep outside the breeding season (Fowler et al., 1992). It is probable that the oocytes are not susceptible to stimulation by LH during these periods.

In response to the highest concentration of GnRH (10 nmol $\mathrm{I}^{-1}$ ), and in the absence of bFF, desensitization of $\mathrm{LH}$ release occurred. Since the final output of LH release is the result of the various actions of $\mathrm{GnRH}$ on self-priming and desensitization, and that of GnSIF/AF, desensitization of the LH response by GnRH may be masked by the ongoing self-priming action of GnRH during incubation with bFF (De Koning et al., 1994). The 

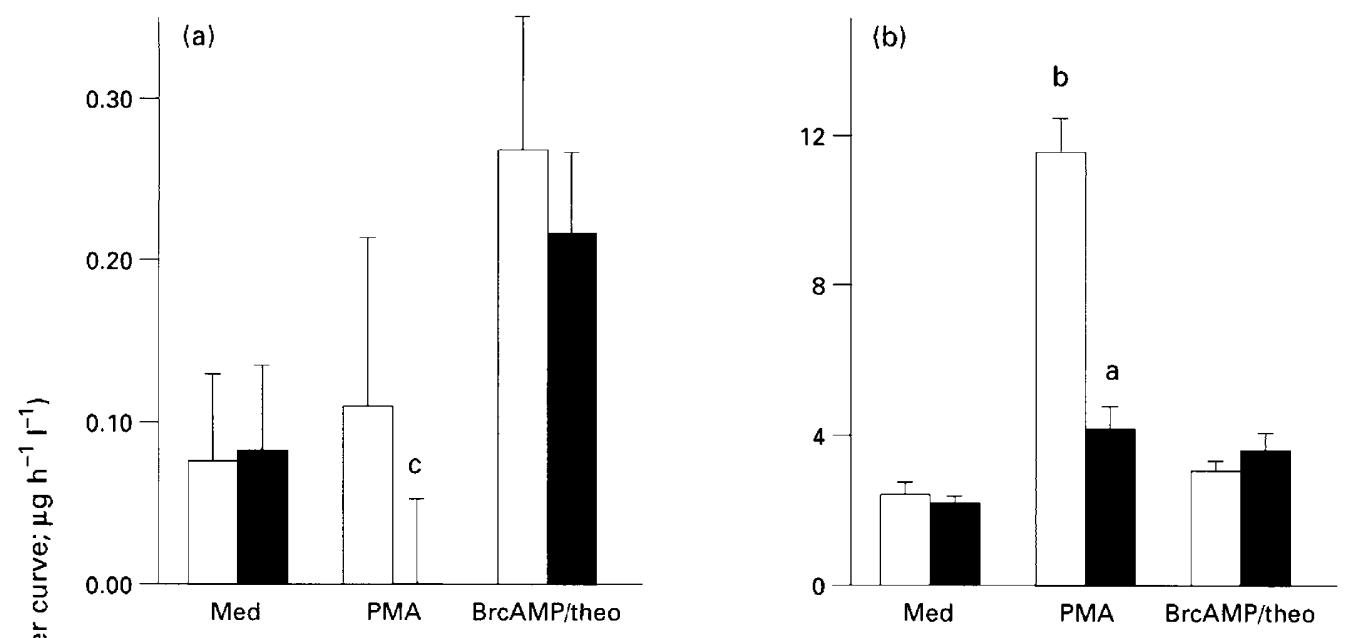

Fifth $10 \mathrm{~min}$ pulse

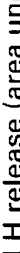

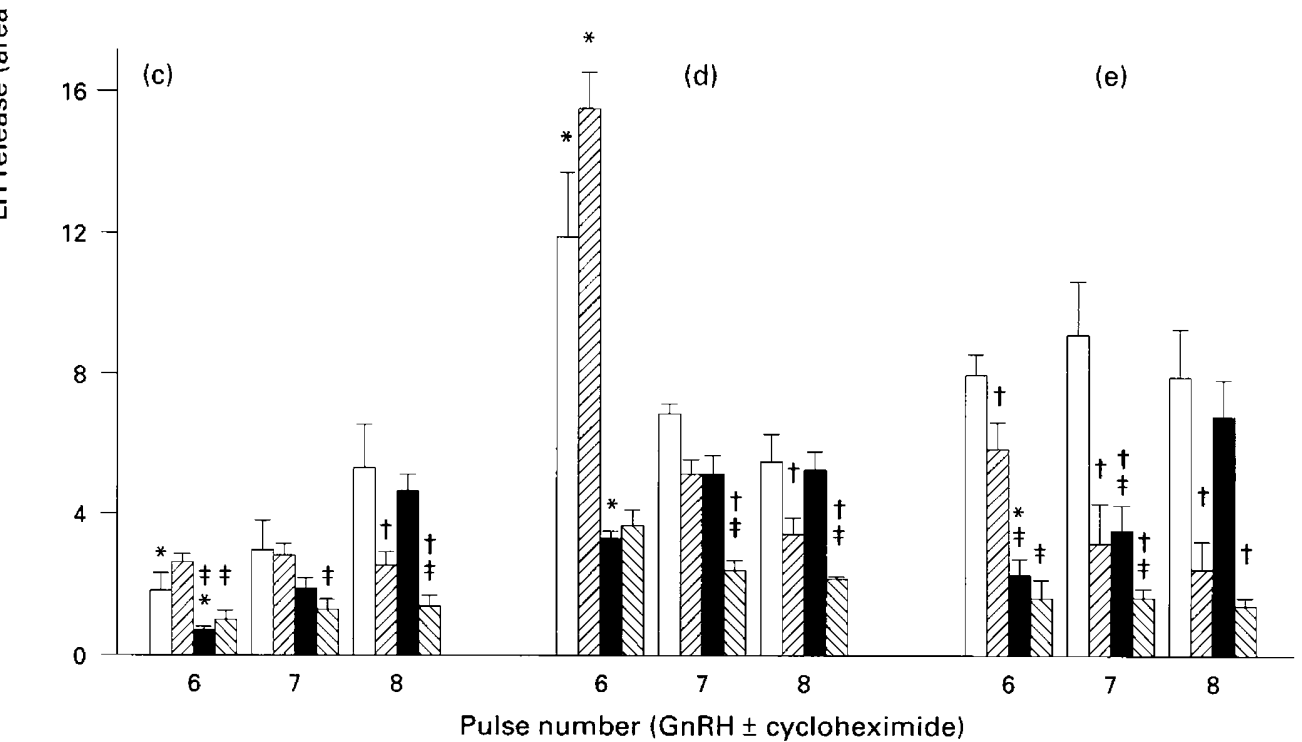

Fig. 4. The effects on LH release ( \pm SEM; $n=6$ ) from hemi-pituitaries taken from rats on day 2 of dioestrus of five successive $10 \mathrm{~min}$ pulses with medium only (Med) or medium containing $1 \mu \mathrm{mol}$ phorbol 12 -myristate 13-acetate (PMA) l-1 or $1 \mathrm{mmol} 8$-bromo-cAMP $\mathrm{l}^{-1}$ plus $10 \mathrm{mmol}$ theophylline (BrcAMP/theo) $\mathrm{l}^{-1}$, all in the absence $(\square, \square)$ or presence $\left(\boldsymbol{\square}, \mathbb{\mathbb { S }}\right.$ ) of $10 \mathrm{ml}$ bovine follicular fluid (bFF) $\mathrm{l}^{-1}$. The pituitaries were challenged by three successive $10 \mathrm{~min}$ pulses with medium containing $10 \mathrm{nmol} \mathrm{GnRH} 1^{-1}$ alone or with $90 \mu \mathrm{mol}$ cycloheximide $\mathrm{l}^{-1}$. In all series the $10 \mathrm{~min}$ pulses were separated by $50 \mathrm{~min}$ of perifusions with medium of the same content as in the preceding 10 min pulse, but without the secretagogues. If added, bFF was present continuously during the $8 \mathrm{~h}$ perifusions. The effects on (a) the LH response during the fifth hour (mean area under curves $\mathrm{h}^{-1}$ ) or (b) the absolute LH concentrations during the last 10 min of this hour, of hemi-pituitaries treated during five successive 10 min pulses with medium only or medium containing PMA or BrcAMP/theo all without $(\square)$ or with ( $\boldsymbol{\square}$ ) bFF. The effects on the LH response during the challenge of three successive $10 \mathrm{~min}$ pulses with medium containing $\mathrm{GnRH}$ alone $(\square, \boldsymbol{\square})$ or with cycloheximide $(\square, \mathbb{\nabla})$. The challenges were preceded by five successive 10 min pulses with (c) medium only or (d) medium containing PMA or

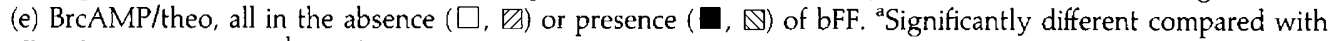
all other treatments; ${ }^{b}$ significantly different compared with the medium control; 'significantly different compared with the BrcAMP/theo treatment; *first LH pulse is significantly lower than all subsequent pulses of the same treatment; ${ }^{\dagger} \mathrm{LH}$ pulses after otherwise the same pretreatment are significantly decreased by bFF; ${ }^{\dagger} \mathrm{LH}$ pulses after the same pretreatment are significantly decreased compared with cycloheximide. In all cases $P<0.05$ (Duncan's multiple comparison test).

effect of the latter action is extended, since it takes more time for $\mathrm{GnRH}$ to neutralize the inhibitory effect of GnSIF/AF on $\mathrm{LH}$ release.
Cyclic AMP and DAG are possible mediators in the protein synthesis-dependent self-priming action of $\mathrm{GnRH}$ (De Koning et al., 1981; Turgeon and Waring, 1986; Bourne et al., 1989; 
Abdilnour and Bourne, 1995; Mitchell et al., 1994; Fink, 1995). Thus, the present data extend previous results by showing that bFF, and by implication GnSIF/AF bioactivity, not only counteracts the action of $\mathrm{GnRH}$ on the self-priming process, but also the priming action of the agents that mimic the action of CAMP and DAG. In the case of DAG, GnRH was able to restore the self-priming action via de novo protein synthesis. This points to interactions between $\mathrm{GnRH}$ and GnSIF/AF bioactivity, within the $\mathrm{GnRH}$-induced cascade of intracellular processes downstream from cAMP and DAG, on protein synthesis-dependent mediators.

The primed state of the pituitary gland, after treatment with PMA or BrcAMP/theo, decayed sharply within Ih when cycloheximide was included in the media. Thus, the maintenance of the increased LH response seems to be dependent on the continuous synthesis of protein. This is in contrast to earlier observations when static culture systems were applied (De Koning et al., 1979, 1980, 1981). This difference may point to the disappearance of agents within the perifusion medium and, thus, may indicate autocrine or paracrine interactions of such agents on LH release in the pituitary gland (Weiss and Jameson, 1993).

It should be noted that PMA and BrcAMP/theo have no significant effects on $\mathrm{LH}$ release in terms of the $\mathrm{LH}$ responses $\mathrm{h}^{-1} \mathrm{l}^{-1}$. However, PMA, but not BrcAMP/theo and GnRH, causes a sustained increase in the absolute rate of $\mathrm{LH}$ release. This increase is blocked by the inclusion of bFF into the media. In agreement with previous observations (De Koning et al, 1981), BrcAMP/theo hardly stimulated the release of LH, but at the same time had a profound priming effect on the pituitary $\mathrm{LH}$ responsiveness to subsequent $\mathrm{GnRH}$ stimulation. The effect of PMA on the absolute LH concentrations may also explain the initial high $\mathrm{LH}$ responsiveness during subsequent stimulation by $\mathrm{GnRH} I \mathrm{~h}$ later and its normalization thereafter. However, this decrease may also be caused by the preceding large amounts of $\mathrm{LH}$ released. It is clear that $\mathrm{bFF}$, and by implication GnSIF/AF, not only acts by inhibiting the formation of SPAP, but also by blocking the direct releasing action of GnRH downstream of DAG formation.

In conclusion, the present results provide further evidence for a role of the putative GnSIF/AF bioactive entity in controlling low concentrations of $\mathrm{LH}$ in the pituitary gland. GnSIF/AF neutralizes the self-priming action of GnRH mediated by the second messengers, CAMP and DAG.

Z-W. Chu was supported financially by the government of the Peoples Republic of China and M.N. Helder was supported by the Netherlands Organization for Scientific Research (NWO), division of Medical Sciences.

\section{References}

Abdilnour G and Bourne GA (1995) Adenosine 3' 5'-cyclic monophosphate and the self-priming effect of gonadotrophin-releasing hormone Molecular and Cellular Endocrinology 107 1-7

Aiyer MS, Chiappa SA and Fink G (1974) A priming effect of luteinizing hormone releasing factor on the pituitary gland in the female rat journal of Endocrinology 62 573-588

Bourne GA, Das S and Fahmy NW (1989) The phorbol ester-induced extracellular $\mathrm{Ca}^{2+}$-independent release of $\mathrm{LH}$ is dependent on estradiol and de novo protein synthesis FEBS Letters 247 159-162
Busbridge NJ, Chamberlain GVP, Griffiths A and Whitehead SA (1990) Nonsteroidal follicular factors attenuate the self-priming action of gonadotropinreleasing hormone on the pituitary gonadotroph Neuroendocrinology 51 493-499

Campen CA and Vale W (1988) Interaction between purified ovine inhibin and steroids on the release of gonadotropins from cultured rat pituitary cells Endocrinology 88 1320-1328

Culler MD (1992) In vivo evidence that inhibin is a gonadotropin surgeinhibiting/attenuating factor Endocrinology 131 1556-1558

Culler MD and Negro-Villar A (1989) Endogenous inhibin suppresses only basal follicle-stimulating hormone secretion but suppresses all parameters of pulsatile luteinizing hormone secretion in the diestrus female rat Endocrinology 124 2944-2953

Danforth DG and Cheng CY (1995) Purification of a candidate gonadotropin surge inhibiting factor from porcine follicular fluid Endocrinology 136 $1658-1665$

De Koning J (1995) Gonadotrophin surge-inhibiting/attenuating factor governs LH secretion during the cycle: physiology and pathology Human Reproduction 10 2854-2861

De Koning J, van Dieten JAMJ and van Rees GP (1976) LH-RH-dependent synthesis of protein necessary for $\mathrm{LH}$ release from pituitary glands in vitro Molecular and Cellular Endocrinology 5 151-160

De Koning J, van Dieten JAMJ and van Rees GP (1979) Studies on a protein synthesis dependent step in LH release by LH-RH Acra Endocrinologica 92 648-657

De Koning J, van Dieten JAMJ and van Rees GP (1980) The pattern of LH release of rat pituitary glands during long-term exposure to LH-RH in vitro. In Synthesis and Release of Adenohypophyseal Hormones pp 639-657 Eds M Jutisz and KW McKerns. Plenum Publishing Corporation, New York

De Koning J, van Dieten JAMJ, Tijssen AMI and van Rees GP (1981) Dependence on protein synthesis of the $\mathrm{N}^{6}$-monobutyryl cyclic AMP plus theophylline-mediated release of luteinizing hormone induced by luteinizing hormone releasing hormone from rat pituitary glands in vitro. Journal of Endocrinology 88 329-338

De Koning J, Tijssen AMI and van Rees GP (1987) The involvement of ovarian factors in maintaining the pituitary glands of female rats in a state of low $\mathrm{LH}$ responsiveness to LHRH Journal of Endocrinology 112 265-273

De Koning J, Tijssen AMI and van Rees GP (1989) The self-priming action of LHRH increases the low pituitary LH and FSH response caused by ovarian factors: observations in vitro. Journal of Endocrinology 120 439-447

De Koning J, Westhoff WE, Koppenhaal DW and van Dieten JAMJ (1994) On the dynamics between gonadotrophin surge-inhibiting factor and gonadotrophin releasing hormone $(\mathrm{GnRH})$; role of self-priming and desensitization in the luteinizing hormone response to $\mathrm{GnRH}$ after follicle stimulating hormone treatment Human Reproduction 9 1600-1606

Evans WS, Uskavitch DR, Kaiser DL, Helmann P, Borges JLC and Thorner MO (1984) The self-priming effect of gonadotropin-releasing hormone on luteinizing hormone release: observations using rat anterior pituitary fragments and dispersed cells continuously perifused in parallel Endocrinology $114861-867$

Farnworth PG, Robertson DM, de Kretser DM and Burger HG (1988) Effects of $31 \mathrm{kDa}$ bovine inhibin on $\mathrm{FSH}$ and $\mathrm{LH}$ in rat pituitary cells in vitro: antagonism of gonadotrophin-releasing hormone agonists Journal of Endocrinology $119233-241$

Fink G (1995) Commentary: the self-priming effect of LHRH: a unique servomechanism and possible cellular model for memory Frontiers in Neuroendocrinology 16 183-90

Fowler PA and Templeton A (1996) The nature and function of putative gonadotropin surge-attenuating/inhibiting factor (GnSAF/IF) Endocrine Reviews 17 103-120

Fowler PA, Townsend C, Messinis IE, Cunningham P and Templeton AA (1992) Gonadotrophin surge-attenuating factor attenuates in-vitro LH secretion induced by gonadotrophin-releasing hormone from cultured ovine pituitary cells only during the breeding season Journal of Endocrinology 135 221-227

Gallo RV (1981a) Pulsatile LH release during the ovulatory LH surge on proestrus in the rat Biology of Reproduction 24 100-104

Gallo RV (1981b) Pulsatile LH release during periods of low level LH secretion in the rat estrous cycle Biology of Reproduction 24 771-777

Jakubowiak A, Janecki A and Steinberger A (1989) Similar effects of inhibin and cycloheximide on gonadotropin release in superfused pituitary cell cultures Biology of Reproduction 41 454-463 
Jakubowiak A, Janecki A and Steinberger A (1990) Action kinetics of inhibin in superfused pituitary cells dependent on gonadotropin-releasing hormone treatment Endocrinology 127 211-217

Kalra SP (1993) Mandatory neuropeptide-steroid signaling for the preovulatory luteinizing hormone-releasing hormone discharge Endocrine Reviews 14 507-538

Knight PC, Lacey M, Peter LJT and Whitehead SA (1990) Demonstration of a nonsteroidal factor in human follicular fluid that attenuates the self-priming action of gonadotropin-releasing hormone on pituitary gonadotropes Biology of Reproduction 42 613-618

Koppenaal DW, Tijssen AMI, van Dieten JAMJ and de Koning J (1991) The selfpriming action of LHRH is under negative FSH control through a factor released by the ovary: observations in female rats in vitro. Journal of Endocrinology 129 205-211

Koppenaal DW, van Dieten JAMJ, Tijssen AMI and de Koning J (1993) Induction of the gonadotrophin surge-inhibiting factor by FSH and its elimination: a sex difference in the efficacy of the priming effect of gonadotrophinreleasing hormone in the rat pituitary gland Journal of Endocrinology 138 191-201

Mitchell R, Sim PJ, Leslie T, Johnson M and Thomas FJ (1994) Activation of MAP kinase associated with the priming effect of LHRH Journal of Endocrinology 140 R15-R18

Muttukrishna S, Fowler PA, Groome NP, Mitchell GG, Robertson WR and Knight PG (1994) Serum concentrations of dimeric inhibin during the spontaneous human menstrual cycle and after treatment with exogenous gonadotrophin Human Reproduction 9 1634-1642

Padmanabhan V, Leung K and Convey EM (1982) Ovarian steroids modulate the self-priming effect of luteinizing hormone-releasing hormone on bovine pituitary cells in vitro. Endocrinology $110717-721$

Pickering AJMC and Fink G (1976) Priming effect of luteinizing hormone releasing factor: in-vitro and in-vivo evidence consistent with its depen- dence upon protein and RNA synthesis Journal of Endocrinology 69 373-379

Schuiling GA, de Koning J, Zürcher AF, Gnodde HP and van Rees GP (1976) Induction of LH surges by continuous infusion of LHRH Neuroendocrinology 20 151-156

Steel RGD and Torrie JH (1960) Principles and Procedures of Statistics McGrawHill, New York

Tio S, Koppenaal DW, Cheng CY and Bardin W (1994) Purification of gonadotropin-surge inhibiting factor (GnSIF) from Sertoli-cell enriched culture medium Biochemical and Biophysical Research Communications 199 1229-1236

Turgeon JL and Waring DW (1986) cAMP augmentation of secretagogueinduced luteinizing hormone secretion American Journal of Physiology 250 E62-E68

Van Dieten JAMJ and de Koning J (1995) From basal luteinizing hormone (LH) concentrations to the pre-ovulatory LH surge: titration of the physiological effect of gonadotrophin surge-inhibiting/attenuating factor Human Reproduction $103110-3116$

Waring DW and Turgeon JL (1980) Luteinizing hormone-releasing hormoneinduced luteinizing hormone secretion in vitro: cyclic changes in responsiveness and self-priming Endocrinology 106 1430-1436

Weiss J and Jameson JL (1993) Perifused pituitary cells as a model for studies of gonadotropin biosynthesis and secretion Trends in Endocrinology and Metabolism 4 265-270

Weiss J, Crowley WF, Halvorson LM and Jameson JL (1993) Perifusion of rat pituitary cells with gonadotropin-releasing hormone, activin, and inhibin reveals distinct effects on gonadotropin gene expression and secretion Endocrinology 132 2307-2311

Woodruff TK, Krummen LA, Lyon RJ, Stocks DL and Mather JP (1993) Recombinant human inhibin $A$ and recombinant human activin $A$ regulate pituitary and ovarian function in the adult female rat Endocrinology 132 2332-234I 